\title{
There is no relationship between Paraoxonase serum level activity in women with endometriosis and the stage of the disease: an observational study
}

Felipe Barca Bragatto ${ }^{1,2}$, Caio Parente Barbosa ${ }^{2}$, Denise Maria Christofolini ${ }^{2}$, Carla Peluso ${ }^{2}$, Aline Amaro dos Santos ${ }^{2}$, Fernanda Abani Mafra ${ }^{2}$, Viviane Cavalcanti ${ }^{2}$, Sonia Hix ${ }^{1}$ and Bianca Bianco ${ }^{2^{*}}$

\begin{abstract}
Background: Endometriosis is a chronic condition whose pathophysiology is unknown, but there is evidence suggesting a link with oxidative stress. Paraoxonase is a serum enzyme which circulates associated with high-density lipoprotein (HDL). It acts protecting HDL and LDL of lipid peroxidation. We aimed to compare the serum levels of PON-1 activity in women with endometriosis in different stages of the disease (minimal/mild and moderate/severe).

Methods: 80 infertile women with endometriosis diagnosed by laparoscopy/laparotomy with histologic confirmation of the disease were divided according to the American Society for Reproductive Medicine classification in minimal/mild $(n=33)$ and moderate/severe $(n=47)$ cases. Paraoxonase activity and arilesterase activity were measured by spectrophotometry. Body mass index and fasting glucose levels were also determined.

Results: The paraoxonase activity were 191.29 $\pm 22.41 \mathrm{U} / \mathrm{l}$ in women with minimal/mild endometriosis and $224.85 \pm$ $21.50 \mathrm{U} / \mathrm{I}$ in women with moderate/severe disease $(P=0.274)$. Considering arilesterase level, the results showed $89.82 \pm$ $4.61 \mathrm{U} / \mathrm{l}$ in women with minimal/mild endometriosis and $90.78 \pm 3.43 \mathrm{U} / \mathrm{I}$ in moderate/severe disease $(P=0.888)$.
\end{abstract}

Conclusions: Evidence of lower paraoxonase activity in women with endometriosis was not found in this study. Besides, no difference was found considering minimal/mild or moderate/severe endometriosis.

Keywords: Endometriosis, Paraoxonase, Oxidative stress, Infertility, High-density lipoprotein

\section{Background}

Endometriosis is a chronic condition characterized by tissue histologically similar to the endometrium implants, grows and develops outside the uterine cavity associated with pelvic pain and infertility [1,2]. It affects $3-10 \%$ of women in their reproductive years and $20-50 \%$ of women with infertility [3]. The pathophysiologic mechanism is unknown, but some authors suggest a link with oxidative stress [4-9]. In the presence of pelvic

\footnotetext{
* Correspondence: bianca.bianco@hotmail.com

${ }^{2}$ Human Reproduction and Genetics Center, Department of Gynecology and Obstetrics, Faculdade de Medicina do ABC, Av. Principe de Gales, 821, Santo André/SP, Brazil

Full list of author information is available at the end of the article
}

endometriosis, peritoneal macrophages would be activated, increasing the production of reactive oxygen species (ROS) [4], one of the responsible for the inflammatory reaction observed in endometriosis [6]. Increased levels of lipid peroxidation markers in peritoneal fluids of women with endometriosis [10], like tumor necrosis factor (TNF) $\alpha$, were found in previous published studies [9].

Those markers are chemotactic factors for monocytes and T-lymphocytes, such the T-helper, which immune response has been identified as a main factor in the development and progression of endometriosis [5]. An increase in the oxidation of low-density lipoprotein (LDL) was reported in endometriosis patients [8].

\section{Ciomed Central}


Paraoxonase1 (PON1) is an antioxidant serum enzyme which circulates associated with HDL (High Density Lipoprotein) [11-13]. It hydrolyzes various organophosphate compounds, including pesticides and neurotoxic gases. Its name derives from paraoxon, a metabolite of an ordinary pesticide called parathion, which is hydrolyzed by PON1 with modest catalytic efficiency [13]. The PON1 has an appreciable arylesterase activity, being phenylacetate the typical substrate. Khersonsky et al. [14] suggests that PON1 is in fact,a lactonase and not an esterase or a fosfotriesterase as traditionally described.

PON1 is also involved in the metabolism of drugs, being used for their inactivation [15]. The identity of the native substrate of PON1 and other PON's family enzymes is not known yet. A possible physiological substrate is homocysteine-thiolactone, which may be formed from the non-protein amino acid homocysteine. Serum levels of homocysteine are known as a risk factor for atherosclerotic vascular disease by inducing endothelial injury. One of the potential mechanisms that explain homocysteine's toxic effects is homocysteine-thiolactone's formation, a metabolite that can modify proteins, including the LDL apoprotein B and HDL Apo A, favoring atherogenesis [16].

Paraoxonase features two genetic polymorphisms that results in different paraoxonase activity against the substrate paroxon, particularly when the test is performed in the presence of $\mathrm{NaCl}$ (paraoxonase activity), but not against the substrate phenylacetate (arilesterase activity) [12]. Most studies that have attempted to relate the $\mathrm{PON}_{192}$ polymorphism with diseases, particularly cardiovascular disease, were inconclusive.

This enzyme acts protecting HDL and LDL of lipid peroxidation, degrading cholesterol esters' oxidized lipids and phospholipids present in the lipoproteins, erythrocytes and macrophages. PON1 may otherwise be inactivated by oxidized lipids [17]. Furthermore, PON1 has additional antiatherogenic properties, as inhibition of cholesterol biosynthesis by macrophages and stimulating macrophage cholesterol efflux [18-21]. Paraoxonase activity measurements have shown an inverse association with various morbidities, like obesity, cardiovascular disease, diabetes, metabolic syndrome, and aging, all related with its antioxidant activity [22-25].

Considering the complex cellular and molecular mechanisms involved in endometriosis formation and progression, we aimed to compare the serum levels of PON-1 activity in women with endometriosis in different stages of the disease (minimal/mild and moderate/severe).

\section{Methods}

\section{Patients}

The studied group consisted of 80 infertile women with endometriosis attended at Human Reproduction and Genetics Center of the Faculdade de Medicina do ABC,
Santo André, Brazil. Patients with endometriosis-associated infertility were diagnosed by laparoscopy and classified according to the American Society for Reproductive Medicine [26], with histologic confirmation of the disease. In this group, minimal/mild (stage I and II) endometriosis was found in 33 cases (41.2\%) and moderate/severe (stage III and IV) endometriosis in 47 cases (58.8\%).

The cause of infertility was investigated including a hormonal and biochemical profile, testing for sexually transmitted diseases, imaging examinations, investigation of genetic and/or immunological abnormalities, hysterosalpingography, hysteroscopy and laparoscopy (performed in all women up to 36 years of age and also in patients over 36, whenever there were symptoms or abnormalities on the imaging examinations), and semen analysis of the partner. Women with endometriosis who did not achieve pregnancy after at least twelve natural or induced cycles following laparoscopy were considered infertile. Patients with obesity (BMI $\left.\geq 30 \mathrm{~kg} / \mathrm{m}^{2}\right)$, smokers and with acute or chronic medical conditions and whose partner had any male factors associated with infertility were excluded from the study.

Clinical data and peripheral blood samples were collected only after explaining the objectives of the study and obtaining signed informed consent, as approved by the local Research Ethics Committee.

\section{Laboratory evaluation}

$5 \mathrm{~mL}$ of blood were collected by trained professionals through a peripheral vein, in a room protected from direct light. PON activity was determined in blood samples. The serum was isolated by centrifugation at low speed (5.000 rpm for 3 minutes) after coagulation. The samples were stored at $-80^{\circ} \mathrm{C}$. Paraoxonase activity and arilesterase activity were determined spectrophotometrically using paraoxon and phenylacetate as substrates, respectively.

The paraoxonase activity was determined using a PON paraoxon (diethyl - p-nitrophenyl) as substrate and measuring the increase in absorbance at $412 \mathrm{~nm}$ by the formation of 4 - nitrophenol. The activity was measured at $30^{\circ} \mathrm{C}$ during 90 seconds after $12 \mu \mathrm{l}$ of serum were added to each well containing $238 \mu \mathrm{l}$ of Tris/ $\mathrm{HCl}(100 \mathrm{mmol} / \mathrm{l}, \mathrm{pH} 8.0)$ buffer containing $2 \mathrm{mmol} / \mathrm{l} \mathrm{CaCl}_{2}$ and $5.5 \mathrm{mmol} / \mathrm{l}$ of paraoxon. The regeneration rate of 4-nitrophenol was measured at $412 \mathrm{~nm}$ in a visible plaque spectrophotometer. At the same time the spontaneous hydrolysis of paraoxon was discounted in a reference well containing only the buffer with the reagent. The paraoxonase activity of PON1 was determined in quintuplicate and all results are expressed in $\mathrm{U} / \mathrm{ml}$. The enzyme activity was calculated by the molar extinction coefficient of $17.100 \mathrm{M}^{-1} \cdot \mathrm{cm}^{-1,13}$ One unit of paraoxonase activity is defined as $1 \mathrm{nmol}$ of 4nitrophenol formed per minute. Alternatively paraoxonase 
activity was measured in buffer containing $1 \mathrm{M} \mathrm{NaCl}^{13}$ in order to verify the polymorphism increased activity.

PON1's arilesterase activity in serum was determined spectrophotometrically by using the synthetic substrate phenylacetate. The reaction was started by adding $23 \mathrm{ul}$ of phenylacetate $(10 \mathrm{mM})$ to wells containing $5 \mathrm{ul}$ of serum (prediluted 1:13) and $222 \mathrm{uL}$ of buffer $50 \mathrm{mmol} / \mathrm{l}$ Tris $\mathrm{pH} 8.0 / 1 \mathrm{mmol} \mathrm{CaCl}_{2}$. The production of phenol was determined spectrophotometrically during 1 minute at $270 \mathrm{~nm}$, using a molar extinction coefficient of 1310/mol/ $\mathrm{cm}$ at $\mathrm{pH}$ 8.0. The spontaneous hydrolysis of paraoxon was discounted measuring the absorbance in a well containg only the buffer and phenylacetate. The PON1's arilesterase activity was determined in quintuplicate and all results were expressed as $\mathrm{U} / \mathrm{ml}$. $1 \mathrm{U}$ of phenylacetate hydrolyses $1 \mu \mathrm{mol}$ arilesterase per minute [22-24].

BMI was calculated according to the Quetelet formula, by dividing the weight in kilogram by the squared height in metres $(\mathrm{kg} / \mathrm{m} 2)$. The blood glucose level was determined using commercially available assay kits. The patients were fasting for at least 8 hours before their blood were collected for laboratory glucose level evaluation.

\section{Statistical analyses}

Statistical analyses were made using Minitab 16 for Windows [27]. We assumed a significance level of 0.05 for the statistical tests. Normality of data distribution of women with minimal/mild and moderate/severe endometriosis for both enzymes were verified using the Anderson-Darling normality test. Differences among the minimal/mild and moderate/severe endometriosis for PON1's paraoxonase and arilesterase activity were assessed using the Mann-Whitney $U$ test. Correlation between PON1's paraoxonase and arilesterase activity and clinical severity of the disease was performed by Sperman's rank test.

\section{Results}

The group mean age was $33.5 \pm 7.5$ years, with a mean body mass index (BMI) of $24.02 \pm 5.88 \mathrm{~kg} / \mathrm{m}^{2}$. The mean fasting glucose levels were $93 \pm 26 \mathrm{mg} / \mathrm{dl}$.

The serum PON1's paraoxonase and arilesterase activities in each group are presented in Table 1. We did not

Table 1 Serum PON1's paraoxonase and arilesterase activities in women with minimal/mild and moderate/ severe endometriosis \pm (standard deviation) and $\mathbf{P}$ significance level

\begin{tabular}{lcc}
\hline & $\begin{array}{c}\text { Minimal/mild } \\
\text { endometriosis }\end{array}$ & $\begin{array}{c}\text { Moderate/severe } \\
\text { endometriosis }\end{array}$ \\
\hline PON1's paraoxonase activity $(\mathrm{U} / \mathrm{l})$ & $191.29 \pm 22.41^{\mathrm{a}}$ & $224.85 \pm 21.50$ \\
PON1's arilesterase activity $(\mathrm{U} / \mathrm{l})$ & $89.82 \pm 4.61^{\mathrm{b}}$ & $90.78 \pm 3.43$ \\
\hline
\end{tabular}

${ }^{a} P=0.274$ vs women with Moderate/severe endometriosis.

${ }^{b} P=0.888$ vs women with Moderate/severe endometriosis. find any difference in women with minimal/mild and moderate/severe endometriosis for both enzymes, even when the patients were analyzed separately according to endometriosis stage (I, II, III and IV endometriosis).

\section{Discussion}

In the present study, we hypothesized a possible relation between paraoxonase activity and endometriosis development. However, we found no difference between the PON1's paraoxonase and arilesterase activity comparing the group with minimal/mild stage disease with the one with moderate/severe endometriosis. Besides, there was no correlation with the stage of the disease and PON1's activity. Analysis considering the four stages separately was performed, but it also did not showed positive correlation.

Verit et al. [10] have supposed, previously, the association of PON1's activity and endometriosis. The authors studied 87 women who underwent laparoscopy or laparotomy (40 control patients with no pathologic findings; 24 women with minimal/mild endometriosis and 23 women with moderate/severe endometriosis). PON-1 activity was significantly higher in women with moderate/severe endometriosis than in women with minimal/mild disease and controls, and in women with minimal/mild endometriosis compared with control groups $(\mathrm{P}<0.0001$, for all). A significant negative correlation was found between PON-1 activity and stage of the disease ( $\mathrm{r} 520.74, \mathrm{P}<0.0001)$. The authors conclude that PON-1 activity can be used as a diagnostic test to detect endometriosis.

Although we didn't have a control group, the average activity of the enzyme we found in this study was not very different from the activity found by other studies in women without endometriosis $(183.7 \pm 22.3 \mathrm{U} / \mathrm{l}$ in 40 women with no endometriosis in the study of Verit et al., 2008 [10]; $258.29 \pm 101.95 \mathrm{U} / \mathrm{l}$ in 22 adult females with no endocrine or metabolic disorders or history of drug use in the study of Ozenoglu et al., 2008 [28]; and $240 \pm 144 \mathrm{U} / \mathrm{l}$ in 200 individual, both men and women, from blood bank serum samples in a study performed by Davis et al., 2009 [29]). Besides, in our study the patients were diagnosed with endometriosis by laparoscopy/ laparotomy, and classified according to the American Society for Reproductive Medicine [26] with histological confirmation of the disease, which gives a more accurate diagnosis of the stage of the endometriosis in comparison with visual confirmation alone. Barbosa et al. (2009) [2] observed endometriosis in healthy peritoneum biopsy of fertile and asymptomatic women, showing the importance of histological confirmation for minimal/ mild endometriosis.

Studies involving PON1 have attributed an antioxidant and ateroprotector role to it. They have demonstrated that reduced paraoxonase activity are observed in adults with various diseases such as diabetes mellitus, renal 
failure, obesity, and cardiovascular disease [24,25,30-32]. Others have shown an increased activity of PON1 in individuals who maintains a physical activity routine, which is a protective factor against cardiovascular disease by improving the quality of their HDL $[11,33]$. However, there is no clear evidence that women with endometriosis have more atherosclerosis than the general population $[34,35]$.

Despite the evidence that oxidative stress may play a role in endometriosis [4-9], there are other theories that may explain the pathophysiology of this disease. The implantation theory proposes that the retrograde menstruation may result in implantation and growth of endometrial cavity. The coelomic metaplasia suggests that there's a transformation of peritoneal in mullerian cells, activated by hormones. Combining the two previous theories, the induction theory attributes to immunological and endogenous biochemical factors the induction of the differentiation of undifferentiated cells into endometrial tissue. Finally, recent studies have shown genetic predisposition and familial tendency of endometriosis. None of these theories alone have succeeded to determine the mechanism of the disease [25].

Some authors have also suggested the possibility of endometriosis is a disease caused or associated with oxidative stress [36-40]. In the presence of pelvic endometriosis, there was activation of macrophages in the peritoneal cavity, which could promote increased production of reactive oxygen species and nitrogen and, consequently, oxidative stress, resulting in lipid peroxidation, its degradation products and the products formed by its interaction with low-density lipoproteins and other proteins [41]. Oxidized lipids, to decompose, generate products such as malondialdehyde and could be recognized as foreign, antigenic response with consequent triggering antibody production. This process leads to oxidative damage to red blood cells, and peritoneal endometrial cells which, in turn, stimulate the recruitment and activation of mononuclear phagocytes further perpetuating oxidative damage in the pelvic cavity. Oxidative stress also damages mesothelial cells and can induce the appearance of adhesion sites for endometrial cells, favoring the development and progression of endometriosis [40,42].

Although there is evidence suggesting the presence of oxidative stress in the sites of pelvic endometrial implants, little is known about the systemic oxidative status in women with infertility related to endometriosis. Likewise, very little is known about the association between disease stage and systemic markers of oxidative stress [40].

The human biological aging is a phenomenon that is associated with changes in the activity of cells, tissues and organs, as well as reducing the effectiveness of a set of processes physiological. With respect to aspects of the endogenous production of oxidants, both the causes and the molecular mechanisms involved this process is not yet sufficiently known. However, evidences attributed to aging palatine accumulation of structural and functional changes in macromolecules and cell membranes, caused by the deleterious effects of free radicals and other reactive oxygen species which form spontaneously in the mitochondria as a consequence of oxidative metabolism [43]. Thus, one of the possible causes of no association between PON activity and endometriosis can also be attributed to the younger age of the patients.

Furthermore, PON's activity varies widely between individuals, partly related to polymorphisms present in population $[23,44,45]$ and to serum HDL's level, as HDL is pointed as the responsible to distribute PON to the tissues, where it could exercise its antioxidant function [46-49].

Because of those difficulties in comparing PON's activity between individuals, we suggest that perhaps a better way of determining the influence of this enzyme in endometriosis in further studies is correlating the same individual PON's activity along the time, with the evolution of the disease and response to treatments, corrected by the patient HDL levels.

In conclusion, evidence of lower paraoxonase activity in women with endometriosis was not found in the present study. Besides, no difference was found considering minimal/mild or moderate/severe endometriosis.

\section{Competing interests}

The authors have no competing interests.

\section{Authors' contributions}

FBB, SH and BB conceived study design. FBB, CP, AAdosS, FAM and VC performed the data collection and analysed data. SH, BB, DC and CPB interpretation the data. All authors were involved in literature search, writing the paper and had final approval of the submitted and published versions. All authors read and approved the final manuscript.

\section{Acknowledgements}

The authors thanks the financial support from FAPESP 2013/12427-9.

\section{Author details}

${ }^{1}$ Division of Biochemistry, Department of Morphology, Faculdade de Medicina do ABC, Santo André, Santo André/SP, Brazil. 'Human

Reproduction and Genetics Center, Department of Gynecology and Obstetrics, Faculdade de Medicina do ABC, Av. Principe de Gales, 821, Santo André/SP, Brazil.

Received: 2 April 2013 Accepted: 11 June 2013

Published: 22 June 2013

\section{References}

1. Barbosa CP, Souza AM, Bianco B, Christofolini D, Mafra FA, Lima GR: Frequency of endometriotic lesions in peritoneum samples from asymptomatic fertile women and correlation with CA125 values. Sao Paulo Med J 2009, 127:342-345.

2. Barbosa CP, Souza AM, Bianco B, Christofolini D: The effects of hormones on endometriosis development. Minerva Ginecol 2011, 63:375-386.

3. Barbosa CP, de Souza AM, Bianco B, Christofolini D, Mafra FA, Lima GR: OC-125 Immunostaining in endometriotic lesion samples. Arch Gynecol Obstet 2010, 281:43-47.

4. De Andrade AZ, Rodrigues JK, Dib LA, Romão GS, Ferriani RA, Junior AAJ, Navarro PAAS: Serum markers of oxidative stress in infertile women with endometriosis. Rev Bras Ginecol Obstet 2010, 32:279-285. 
5. Cabrera JM, Zamudio LJ, Latorre EG, Orozco OC, Guerrero CH: Quantitative and qualitative peritoneal imune profiles. T-cell apoptosis and oxidative stress-associated characteristics in women with minimal and mild endometriosis. BJOG 2011, 118:6-16.

6. Seeber BE, Czech T, Buchner H, Barnhart KT, Seger C, Daxenbichler G, Wildt $\mathrm{L}$, Dieplinger $\mathrm{H}$ : The vitamin $\mathrm{E}$-binding protein afamin is altered significantly in the peritoneal fluid of women with endometriosis. Fertil Steril 2010, 94:2923-2926.

7. Taylor RN, Yu J, Torres PB, Schickedanz AC, Park JK, Mueller MD, Sidell N: Mechanistic and Therapeutic Implications of Angiogenesis in Endometriosis. Reprod Sci 2009, 16:140-146.

8. Gupta S, Agarwal A, Krajcir N, Alvarez JG: Role of oxidative stress in endometriosis. Reprod Biomed Online 2006, 13:126-134.

9. Agarwal A, Gupta S, Sharma RK: Role of oxidative stress in female reproduction. Reprod Biol Endocrinol 2005, 3:28.

10. Verit FF, Erel O, Celik N: Serum paraoxonase-1 activity in women with endometriosis and its relationship with the stage of the disease. Hum Reprod 2008, 23:100-104.

11. Tomás M, Elosua R, Sentí M, Molina L, Vila J, Anglada R, et al: Paraoxonase1192 polymorphism modulates the effects of regular and acute exercise on paraoxonase1 activity. J Lipid Research 2002, 43:713-720.

12. Draganov DI, La Du BN: Pharmacogenetics of paraoxonases: a brief review, Naunyn-Schmiedeberg's Arch. Pharmacol 2002, 369:78-88.

13. La Du BN, Aviram M, Billecke S, Navab M, Primo-Parmo S, Sorenson RC, Standiford TJ: On the physiological role(s) of the paraoxonases. Chem Biol Interact 1999, 119-120:379-388

14. Khersonsky O, Tawfik DS: Structure-Reactivity Studies of Serum Paraoxonase PON1 Suggest that Its Native Activity Is Lactonase. Biochemistry 2005, 44:6371-6382.

15. Biggadike K, Angell RM, Burgess CM, Farrell RM, Hancock AP, Harker AJ Irving WR, loannou C, Procopiou PA, Shaw RE, Solanke YE, Singh OM, Snowden MA, Stubbs RJ, Walton S, Weston HE: Selective plasma hydrolysis of glucocorticoid gammalactones and cyclic carbonates by the enzyme paraoxonase: an ideal plasma inactivation mechanism. J Med Chem 2000, 43:19-21.

16. Ferretti G, Bacchetti T, Nègre-Salvayre A, Salvayre R, Dousset N, Curatola G: Structural modifications of HDL and functional consequences. Atherosclerosis 2006, 184:1-7.

17. Camps J, Marsillach J, Joven J: The paraoxonases: role in human diseases and methodological difficulties in measurement. Crit Rev Clin Lab Sci 2009, 46:83-106

18. Rozenberg O, Rosenblat M, Coleman R, Shih DM, Aviram M: Paraoxonase (PON1) deficiency is associated with increased macrophage oxidative stress: studies in PON1-knockout mice. Free Radic Biol Med 2003, 34:774-778.

19. Rozemberg O, Shih DM, Aviram M: Paraoxonase 1 (PON1) attenuates macrophage oxidative status: studies in PON1 transfected cells and in PON1 transgenic mice. Atherosclerosis 2005, 181:9-18.

20. Aviram M, Rosenblat M: Paraoxonases 1, 2, and 3, oxidative stress, and macrophage foam cell formation during atherosclerosis development. Free Radical Biol Med 2004, 9:1304-1316.

21. Ferretti G, Bacchetti T, Moroni C, Savino S, Liuzzi A, Balzola F, Bicchiega V: Paraoxonase activity in high-density lipoproteins: a comparison between healthy and obese females. J Clin Endocrinol Metab 2005, 3:1728-1733.

22. Rosenblat M, Vaya J, Shih DM, Aviram M: Paraoxonase 1 (PON1) enhances HDL-mediated macrophage cholesterol efflux via the ABCA1 transporter in association with increased HDL binding to the cells: a possible role for lysophosphatidylcholine. Atherosclerosis 2005, 179:69-77.

23. She M, Chen H, Yan Y, Li H, Liu D: The human paraoxonase gene cluster as a target in the treatment of atherosclerosis. Antioxid Redox Signal 2012, 16:597-632.

24. Gur M, Aslan M, Yildiz A, Demirbag R, Yilmaz R, Selek S, Erel O, Ozdogru I: Paraoxonase and arylesterase activities in coronary artery disease. Eur J Clin Invest 2006, 36:779-787.

25. Marsillach J, Camps J, Beltran-Debón R, Rull A, Aragones G, Maestre-Martínez C, Sabench F, Hernández M, Castillo DD, Joven J, Mackness M, Mackness B: Immunohistochemical analysis of paraoxonases-1 and 3 in human atheromatous plaques. Eur J Clin Invest 2011, 41:308-314.

26. Revised American Society for Reproductive Medicine classification of endometriosis. Fertil Steril 1997, 67:817-821.
27. Minitab 16 Statistical Software. Windows. State College, PA: Minitab, Inc 2010. www.minitab.com

28. Ozenoglu A, Balci H, Ugurlu S, Caglar E, Uzun H, Sarkis C, Gunay C, E, EE: The relationships of leptin, adiponectin levels and paraoxonase activity with metabolic and cardiovascular risk factors in females treated with psychiatric drugs. Clinics (Sao Paulo) 2008, 63:651-660.

29. Davis K, Crow J, Chambers H, Meek E, Chambers J: Racial Differences in Paraoxonase-1 (PON1): A Factor in the Health of Southerners? Environ Health Perspect 2009, 117:1226-1238.

30. Ikeda Y, Suehiro T, Inoue M, Nakauchi Y, Morita T, Arii K: Serum paraoxonase activity and its relationship to diabetic complications in patients with non-insulin-dependent diabetes mellitus. Metabolism 1998, 47:598-602.

31. Dirican M, Akca R, Darandol E, Dilek K: Serum paraoxonase activity in uremic predialysis and hemodialysis patients. J Nephrol 2004, 17:813-818.

32. Gur M, Aslan M, Yildiz A, Demirbag R: Paraoxonase and arylesterase activities in coronary artery disease. Eur J Clin Invest 2006, 36:779-787.

33. Brites F, Zago V, Verona J, Muzzio ML, Wikinski R, Schreier L: HDL capacity to inhibit LDL oxidation in well-trained triathletes. Life Sci 2006, 78:3074-3081.

34. Pretta S, Remorgida V, Abbamonte LH, Anserini P, Ragni N, Del Sette M, Gandolfo C, Ferrero S: Atherosclerosis in women with endometriosis. Eur J Obstet Gynecol Reprod Biol 2007, 132:226-231.

35. Melo A, Rosa-e-Silva C, Rosa-e-Silva A, Poli-Neto O, Ferriani R, Vieira C: Unfavorable lipid profile in women with endometriosis. Fertil Steril 2010, 93:2433-2436

36. Agarwal A, Saleh RA, Bedaiwy MA: Role of reactive oxygen species in the pathophysiology of human reproduction. Fertil Steril 2003, 79:829-843.

37. Szczepanska M, Kozlik J, Skrzypczak J, Mikolajczyk M: Oxidative stress may be a piece in the endometriosis puzzle. Fertil Steril 2003, 79:1288-1293.

38. Gupta S, Agarwal, Krajcir N, Alvarez JG: Role of oxidative stress in endometriosis. Reprod Biomed Online 2006, 13:126-134.

39. Gupta S, Goldberg JM, Aziz N, Goldberg E, Krajcir N, Agarwal A: Pathogenic mechanisms in endometriosis-associated infertility. Fertil Steril 2008, 90:247-257

40. Andrade AZ, Rodrigues JK, Dib LA, Romão GS, Ferriani RA, Jordão Junior AA, Navarro PA: Serum markers of oxidative stress in infertile women with endometriosis. Rev Bras Ginecol Obstet 2010, 32:279-285.

41. Augoulea A, Mastorakos G, Lambrinoudaki I, Christodoulakos G, Creatsas G: The role of the oxidative-stress in the endometriosis-related infertility. Gynecol Endocrinol 2009, 25:75-81

42. Alpay Z, Saed GM, Diamond MP: Female infertility and free 11. radicals: potential role in adhesions and endometriosis. J Soc Gynecol Investig 2006, 13:390-398.

43. Rebelatto JR, Jiménez R, Delgado MA, Muguerza B, Muñoz ME, Galan Al, Sánchez RM, Arenillas JIC: Antioxidants. Physical Activity and Oxidative Stress in Older Women. Rev Bras Med Esporte 2008, 14:8-11.

44. Mohamed A, Chia S: Interethnic variability of plasma paraoxonase (PON1) activity towards organophosphates and PON1 polymorphisms among Asian populations-a short review. Ind Health 2008, 46:309-317.

45. Sarandöl E, Dirican M, Eröz E, Kırhan E, Serdar Z: Uncu. Serum Paraoxonase and Arylesterase Activities Throughout normal pregnancy. Nobel Medicus 2010, 19:49-55.

46. Mackness B, Beltran-Debon R, Aragones G, Joven J, Camps J, Mackness M: Human tissue distribution of paraoxonases 1 and 2 mRNA. IUBMB Life 2010, 62:480-482.

47. Camps J, García-Heredia A, Rull A, Alonso-Villaverde C, Aragonès G, Beltrán-Debón R, Rodríguez-Gallego E, Joven J: PPARs in Regulation of Paraoxonases: Control of Oxidative Stress and Inflammation Pathways. PPAR Res 2012, 2012:616371.

48. Deakin S, Bioletto S, Bochaton-Piallat M, James R: HDL-associated paraoxonase-1 can redistribute to cell membranes and influence sensitivity to oxidative stress. Free Radic Biol Med 2011, 1:102-109.

49. James R, Deakin S: The importance of high-density lipoproteins for paraoxonase-1 secretion, stability, and activity. Free Radic Biol Med 2004, 15:1986-1994

\section{doi:10.1186/1742-4755-10-32}

Cite this article as: Bragatto et al:: There is no relationship between Paraoxonase serum level activity in women with endometriosis and the stage of the disease: an observational study. Reproductive Health 2013 $10: 32$. 